\title{
CHEMICAL COMPOSITION AND ANTIOXIDANT ACTIVITY OF THE ESSENTIAL OIL AND FLAVONOIDS OF PHLOMIS FLOCCOSA D. DON.
}

\author{
Rehab A. Lotfy and Heba I. Abd El-Moaty* \\ Department of Medicinal and Aromatic Plants, Desert Research \\ Center, El-Matareya, Cairo, Egypt \\ *E-mail: torkeyheba@yahoo.com
}

$\mathrm{T}$ he present study aimed to investigate the antioxidant activities of essential oils and different extracts from Phlomis floccosa parts. Where the essential oil was detected in the leaves of Phlomis floccosa only, while it was absent in stem and flower parts. The hydro-distillation of the leaves of Phlomis floccosa yielded $0.18 \%$ of clear yellowish liquid oil and it didn't has antioxidants activity. On the other hand, the methanol extracts of different parts of the plant (stems, leaves and flowers) showed high free radical scavenging activity. The DPPH radical scavenging activity of methanol extracts probably related to their flavonoids contents. Hence, methanol extract was analyzed by using HPLC, which revealed that, the plant contained 21 flavonoid compounds in different plant parts (stems, leaves and flowers). The major detected compound of flavonoids was luteolin-6- glucose -8arabinose with percentages of $1234.3 \mathrm{mg} / 100 \mathrm{~g}, 1098.2 \mathrm{mg} / 100 \mathrm{~g}$ and $440.17 \mathrm{mg} / 100 \mathrm{~g}$ for stems, leaves and flowers of Phlomis floccosa, respectively. The second major compound detected in stems and flowers was luteolin-6- arabinose -8- glucose (144.47 $\mathrm{mg} / 100 \mathrm{~g}$ and $375.3 \mathrm{mg} / 100 \mathrm{~g}$, respectively). On the other hand, the second major compound detected in leaves was naringenin $(278.13 \mathrm{mg} / 100 \mathrm{~g})$. According to the obtained results, the methanolic extract of Phlomis floccosa can be considered as an interesting source of natural antioxidant.

Keywords: Phlomis floccosa, antioxidant, essential oil, flavonoids, DPPH scavenging activity

Phlomis floccosa belonging to family Lamiaceae, which includes about 200 genera and 3000 species. Several studies have reported on the antioxidant activity of the Lamiaceae growing in various regions of the world (Barros et al., 2010 and Kamatou et al., 2010). Antioxidants are 
important in reducing heart disease and could prevent damage of DNA in human. Many synthetic antioxidant components have toxic and/or mutagenic effects, which have attracted most of the attention on the natural source of antioxidants. Plants are sources of natural antioxidant, because they contain phenolic compounds; such as phenolic acid, flavonoids, tannins and anthocyanins (Azad et al., 2015). Yumrutas and Saygideger (2012) showed that, the methanol extract of Phlomis armeniaca has high activities in antioxidant assays due to the phenolic content. Delnavazi et al. (2014) demonstrated that, the plants with terpene rich in their oils were suggested as potential sources of free radical-scavenging compounds. Phytochemical investigations of the Phlomis species has been the subject of several studies, which resulted in the isolation of essential oils, flavonoids, iridoids, phenylethylalcohol glycosides and other components and with flavonoids being the major phyto-constituents, isolated from the Phlomis genus (Amor et al., 2009 and $\mathrm{Li}$ et al., 2010). The leaves of Phlomis aurea proved to contain the 7-glucosides, 7-rutinosides and 7-p-coumaroylglucosides of naringenin, apigenin, luteolin and chrysoeriol, hispidulin 7-glucoside, luteolin 7-diglucoside, vicenin-2 and lucenin-2. The microscopic hairs on the leaves only contained the 7-monoglucosides and their acylated derivatives. Phlomis floccosa showed a similar flavonoid pattern, but with no flavanones (El-Negoumy et al., 1986). This research aimed to determine the antioxidant activity of essential oil and compare antioxidant activity of the different extracts of Phlomis floccosa to determine the highest antioxidant activity extract of different plant parts, which it was analyzed by HPLC.

\section{MATERIALS AND METHODS}

\section{Plant Material}

Phlomis floccosa was collected at full flowering stage from MersaMattruh during April 2011, separated to its different parts (stems, leaves and flowers). An amount of $200 \mathrm{~g}$ of each fresh plant part was used to obtain the essential oils. Meanwhile, all collected parts of the plant were air dried, ground to fine powder and kept for further investigations.

\section{Isolation of the Essential Oils}

Fresh stems, leaves and flowers of Phlomis floccosa (200 g) were hydro-distilled in a cleveger-type apparatus (Denny, 1989). After 3 hours of distillation, the essential oils were separated from water, stored in sealed dark glass vials and kept in refrigerator for further analysis.

\section{Extraction of Total Extract}

About $80 \mathrm{~g}$ from each of the stems, leaves and flowers were extracted with $70 \%$ methanol. The obtained residue from each part was dried and weighed. 


\section{Extraction Using Different Organic Solvents Successive extraction technique}

About $700 \mathrm{~g}$ of the stems, leaves and $250 \mathrm{~g}$ of the flowers were subjected to extraction with successive selective organic solvents using soxhlet apparatus, in order of increasing polarity including petroleum ether (b.p. $40-60{ }^{\circ} \mathrm{C}$ ), chloroform, methanol and $50 \%$ methanol. The obtained residue from each solvent was dried and weighed.

\section{Determination of Free Radical Scavenging Activity}

Free radical scavenging assay using 1, 1-diphenyl-2-picrylhydrazyl radical (DPPH) was carried out according to Yildirim et al. (2001). This method is based on the reduction of alcoholic DPPH solution. The odd electron of DPPH shows an absorption maximum at $517 \mathrm{~nm}$ (purple color). As the odd electron of the radical becomes paired off in the presence of a hydrogen donor (the antioxidant), the absorption strength vanishes, and the resulting de-colorization is stoichiometric with respect to the number of electrons captured.

\section{Reagents}

$1 \mathrm{mM}$ 1, 1 Diphenyl-2-picrylhydrazyl (DPPH) (Sigma). A weight of $0.394 \mathrm{~g}$ DPPH was dissolved in 1L of 95\% ethyl alcohol.

Ascorbic acid (vitamin C).

\section{Procedure}

Different concentrations $(125,250,500$ and $1000 \mu \mathrm{g} / \mathrm{ml})$ of each tested extract, volatile oil and ascorbic acid as a reference antioxidant (reference control) were prepared in $80 \%(\mathrm{v} / \mathrm{v})$ ethanol. A volume of $3 \mathrm{ml}$ from each extract and ascorbic acid concentrations were mixed with $1 \mathrm{ml}$ of $1 \mathrm{mM}$ of DPPH radical. A control tube was prepared by mixing $3 \mathrm{ml}$ of $80 \%$ ethyl alcohol with $1 \mathrm{ml}$ of alcoholic solution of DPPH radical. The tubes were kept at room temperature in the dark for $30 \mathrm{~min}$. The degree of disappearance of purple color was measured against blank (80\% ethyl alcohol) at $517 \mathrm{~nm}$.

\section{Calculation}

$$
\% \text { Scavenged DPPH }=\frac{\text { Absorbance of control }- \text { Absorbance of extract }}{\text { Absorbance of control }} \times 100
$$

$\mathrm{IC}_{50}$ was defined as the concentration that reduced 50\% DPPH free radicals compared with the reference antioxidant compound, and calculated by means of Graph Pad Prism software (Ver. 4).

\section{Qualitative and Quantitative Analysis of the Highest Antioxidant Activity Containing Extracts by HPLC}

The highest antioxidant activity containing extract of different parts of Phlomis floccosa were analyzed by HPLC. The analytical HPLC system 
employed consisted of HP 1090M Series II high performance liquid chromatography equipped with an HP 1090M Series II diode array and an eight-channel electrochemical colorimetric array detector (EC; Esa Inc., USA). The EC was operated using $100-800 \mathrm{mV}$ potentials $(100 \mathrm{mV}$ intervals). The detector array was housed in a temperature-regulated compartment at $35^{\circ} \mathrm{C}$. Flavonoid separation was done by ODS-3 $(4.0 \times 150$ $\mathrm{nm}, 3 \mu \mathrm{m}$ ) column with a $\mathrm{C}-18$ guard column, with temperature set at $35^{\circ} \mathrm{C}$. The flow rate of the mobile phase was $0.7 \mathrm{ml} / \mathrm{min}$, and the injection volumes were $10 \mu \mathrm{l}$ of the standards and sample extracts. All flavonoids were quantified using the external standard method. Quantification was based on peak area (DAD) or beak height (EC) (Mattila et al., 2000).

\section{RESULTS AND DISCUSSION}

\section{Essential Oils}

The essential oil was detected in the leaves of Phlomis floccosa only, while it was absent in stem and flower parts. The hydro distillation of the leaves of Phlomis floccosa yielded $0.18 \%$ of clear yellowish liquid oil.

\section{Extract Residues of Different Parts of Phlomis floccosa}

The obtained data show that, total extract residues ( $70 \%$ methanol) of stems, leaves and flowers of Phlomis floccosa were 8.36, 15.0 and $14.62 \%$, respectively. The successive extraction using different organic solvents revealed that, the methanol extract residues had the highest values of $4.75,5.36$ and $7.51 \%$, obtained from stems, leaves and flowers, respectively (Table 1 ).

Table (1). Successive extract residues (\%) of stems, leaves and flowers of Phlomis floccosa.

\begin{tabular}{lccc}
\hline Solvent used & \multicolumn{3}{c}{ Residue percentage (\%) } \\
\cline { 2 - 4 } & Stems & Leaves & Flowers \\
\hline Petroleum ether & 1.17 & 4.77 & 2.40 \\
Chloroform & 1.18 & 1.03 & 1.50 \\
Methanol & 4.75 & 5.36 & 7.51 \\
Methanol (50\%) & 2.80 & 3.04 & 4.95 \\
\hline
\end{tabular}

\section{Free Radical Scavenging Activity of Different Parts of Phlomis floccosa}

Antioxidant activity of volatile oil and for each of the stems, leaves and flowers different extracts of Phlomis floccosa were illustrated in tables (2, 3 and 4$)$ and figs. (1,2 and 3). 
Table (2). The percentages of scavenging activities for total extract and successive extraction residues of Phlomis floccosa stems.

\begin{tabular}{ccccccc}
\hline $\begin{array}{c}\text { Concentration } \\
(\boldsymbol{\mu g} / \mathbf{m l})\end{array}$ & $\begin{array}{c}\text { \% } \\
\text { Sacvenging } \\
\text { of total } \\
\text { extract }\end{array}$ & $\begin{array}{c}\text { Scavenging } \\
\text { of } \\
\text { petroleum } \\
\text { ether } \\
\text { fraction }\end{array}$ & $\begin{array}{c}\text { Scavenging } \\
\text { of } \\
\text { chloroform } \\
\text { fraction }\end{array}$ & $\begin{array}{c}\text { Scavenging } \\
\text { of } \\
\text { methanol } \\
\text { fraction }\end{array}$ & $\begin{array}{c}\text { Scavenging } \\
\text { of 50\% } \\
\text { methanol } \\
\text { fraction }\end{array}$ & $\begin{array}{c}\text { Scavenging } \\
\text { of ascorbic } \\
\text { acid }\end{array}$ \\
\hline 1000 & $94.411 \pm$ & $78.368 \pm$ & $86.215 \pm$ & $91.907 \pm$ & $86.372 \pm$ & $97.167 \pm$ \\
& 0.320 & $0.579^{*}$ & 0.167 & 0.229 & 0.898 & 0.177 \\
500 & $93.033 \pm$ & $59.765 \pm$ & $83.307 \pm$ & $89.367 \pm$ & $83.517 \pm$ & $96.230 \pm$ \\
& 0.100 & $0.883^{*}$ & 0.132 & 0.308 & 0.547 & 0.165 \\
250 & $87.834 \pm$ & $39.535 \pm$ & $59.713 \pm$ & $81.205 \pm$ & $74.114 \pm$ & $94.100 \pm$ \\
& 0.184 & $0.423^{*}$ & 0.160 & 0.577 & 0.264 & 0.211 \\
125 & $81.000 \pm$ & $18.620 \pm$ & $36.539 \pm$ & $69.413 \pm$ & $62.512 \pm$ & $90.500 \pm$ \\
& 0.058 & $0.369^{*}$ & 0.219 & 1.130 & 0.421 & 0.188 \\
\hline
\end{tabular}

Values are given as mean \pm S. D. $(n=3)$. *Significant at $\mathrm{p}<0.05$, p-value was calculated by comparing with standard (ascorbic acid) by ANOVA followed by Dunnett's test.

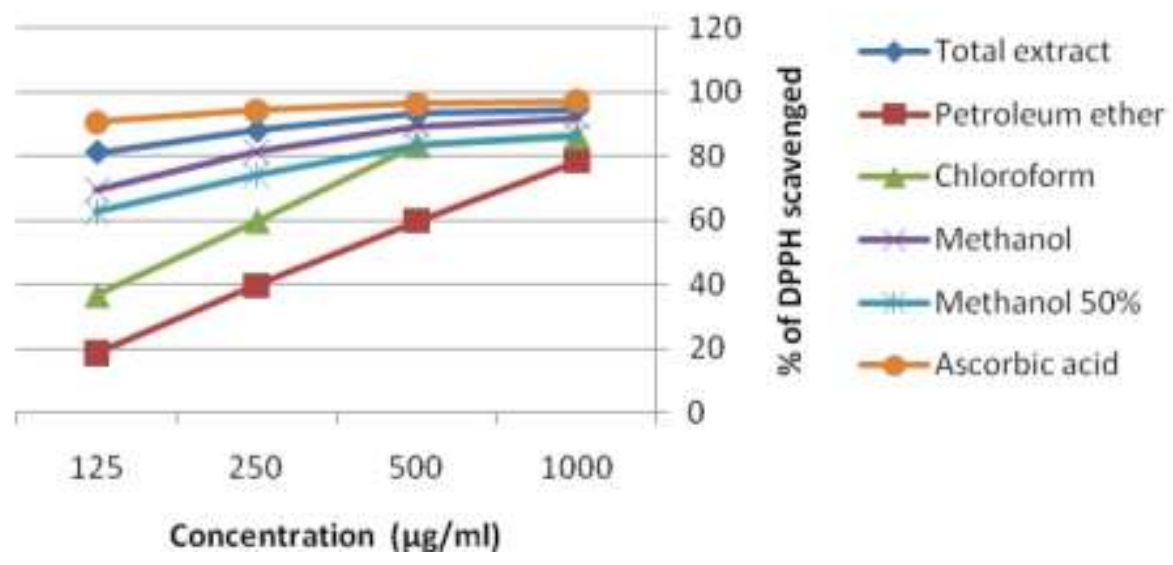

Fig. (1). The percentages of DPPH scavenging activities for total extract and successive extraction residues of Phlomis floccosa stems. 
Table (3). The percentages of scavenging activities for essential oil, total extract and successive extraction residues of Phlomis floccosa leaves.

\begin{tabular}{ccccccccc}
\hline $\begin{array}{c}\text { Concentration } \\
(\boldsymbol{\mu g} / \mathbf{m l})\end{array}$ & $\begin{array}{c}\text { \% } \\
\text { Sacvenging } \\
\text { of volatile } \\
\text { oil }\end{array}$ & $\begin{array}{c}\text { Sacvenging } \\
\text { of total } \\
\text { extract }\end{array}$ & $\begin{array}{c}\text { Scavenging } \\
\text { of } \\
\text { petroleum } \\
\text { ether } \\
\text { fraction }\end{array}$ & $\begin{array}{c}\text { Scavenging } \\
\text { of } \\
\text { chloroform } \\
\text { fraction }\end{array}$ & $\begin{array}{c}\text { Scavenging } \\
\text { of } \\
\text { methanol } \\
\text { fraction }\end{array}$ & $\begin{array}{c}\text { Scavenging } \\
\text { of 50\% } \\
\text { methanol } \\
\text { fraction }\end{array}$ & $\begin{array}{c}\text { Scavenging } \\
\text { of ascorbic } \\
\text { acid }\end{array}$ \\
\hline 1000 & 0 & $94.822 \pm$ & $60.267 \pm$ & $54.389 \pm$ & $97.633 \pm$ & $81.689 \pm$ & $97.167 \pm$ \\
& & 0.204 & $0.145^{* * *}$ & $0.317 * * *$ & 0.034 & $0.201 *$ & 0.177 \\
500 & 0 & $92.600 \pm$ & $48.967 \pm$ & $47.967 \pm$ & $96.000 \pm$ & $69.333 \pm$ & $96.230 \pm$ \\
& & 0.241 & $0.134^{* * *}$ & $0.219^{* * *}$ & 0.167 & $0.088^{*}$ & 0.165 \\
250 & 0 & $88.689 \pm$ & $26.889 \pm$ & $20.901 \pm$ & $92.567 \pm$ & $55.111 \pm$ & $94.100 \pm$ \\
& & 0.279 & $0.386^{* * *}$ & $0.147 * * *$ & 0.120 & $0.102^{*}$ & 0.211 \\
125 & 0 & $83.055 \pm$ & $16.967 \pm$ & $8.011 \pm$ & $87.333 \pm$ & $35.689 \pm$ & $90.500 \pm$ \\
& & 0.267 & $0.121^{* * *}$ & $3.197 * * *$ & 0.318 & $0.234^{*}$ & 0.188 \\
\hline
\end{tabular}

Values are given as mean \pm S. D. $(n=3)$. *Significant at $\mathrm{p}<0.05$, p-value was calculated by comparing with standard (ascorbic acid) by ANOVA followed by Dunnett's test.
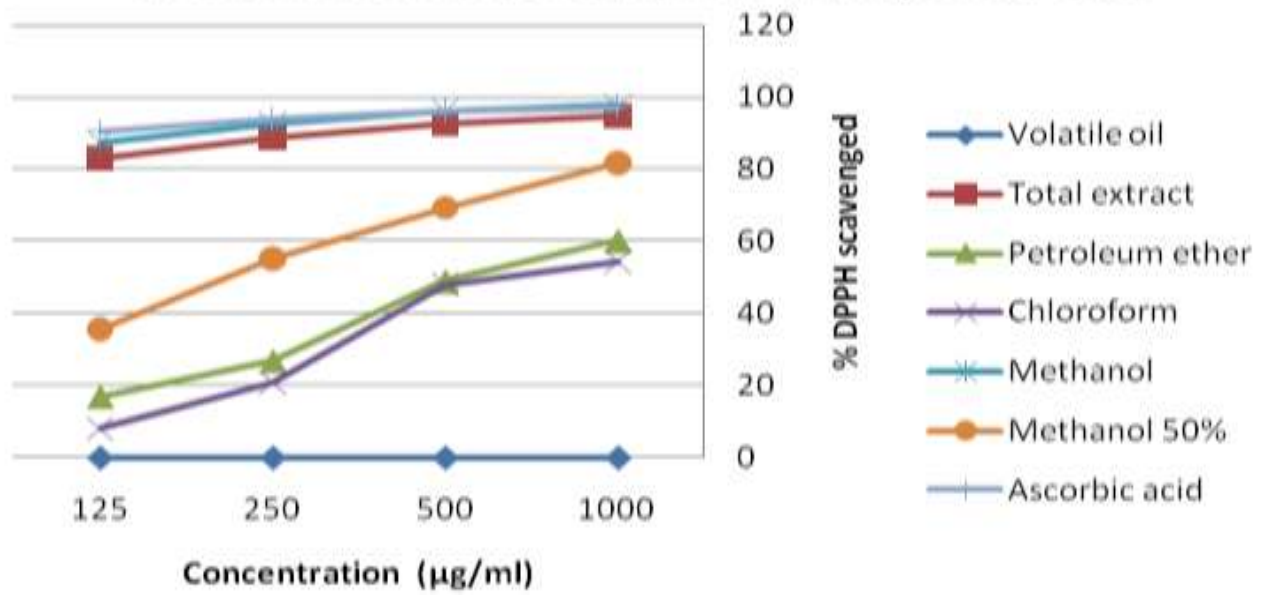

Fig. (2). The percentages of scavenging activities for essential oil, total extract and successive extraction residues of Phlomis floccosa leaves. 
Table (4). The percentages of scavenging activities for total extract and successive extraction residues of Phlomis floccosa flowers.

\begin{tabular}{ccccccc}
\hline $\begin{array}{c}\text { Concentration } \\
(\boldsymbol{\mu g} / \mathbf{m l})\end{array}$ & $\begin{array}{c}\text { \% } \\
\text { Scavenging } \\
\text { of total } \\
\text { extract }\end{array}$ & $\begin{array}{c}\text { Scavenging } \\
\text { of } \\
\text { petroleum } \\
\text { ether } \\
\text { fraction }\end{array}$ & $\begin{array}{c}\text { Scavenging } \\
\text { of } \\
\text { chloroform } \\
\text { fraction }\end{array}$ & $\begin{array}{c}\text { Scavenging } \\
\text { of } \\
\text { methanol } \\
\text { fraction }\end{array}$ & $\begin{array}{c}\text { Scavenging } \\
\text { of 50\% } \\
\text { methanol } \\
\text { fraction }\end{array}$ & $\begin{array}{c}\text { Scavenging } \\
\text { of ascorbic } \\
\text { acid }\end{array}$ \\
\hline 1000 & $93.667 \pm$ & $51.478 \pm$ & $44.611 \pm$ & $95.167 \pm$ & $88.355 \pm$ & $97.167 \pm$ \\
& 0.134 & $0.246 * * *$ & $0.350^{* * *}$ & 0.318 & 0.267 & 0.177 \\
500 & $92.800 \pm$ & $31.589 \pm$ & $38.567 \pm$ & $94.700 \pm$ & 85.744 & $96.230 \pm$ \\
& 0.119 & $0.342^{* * *}$ & $0.153 * * *$ & 0.186 & 0.084 & 0.165 \\
250 & $90.544 \pm$ & $12.389 \pm$ & $34.834 \pm$ & $93.444 \pm$ & $81.278 \pm$ & $94.100 \pm$ \\
& 0.269 & $0.336 * * *$ & $0.153 * * *$ & 0.164 & 0.234 & 0.211 \\
125 & $88.145 \pm$ & $2.255 \pm$ & $32.656 \pm$ & $90.167 \pm$ & $75.522 \pm$ & $90.500 \pm$ \\
& 0.204 & $0.227 * * *$ & $0.269^{* * *}$ & 0.233 & 0.395 & 0.188 \\
\hline
\end{tabular}

Values are given as mean $\pm \mathrm{S}$. D. $(\mathrm{n}=3)$. *Significant at $\mathrm{p}<0.05$, $\mathrm{p}$-value was calculated by comparing with standard (ascorbic acid) by ANOVA followed by Dunnett's test.
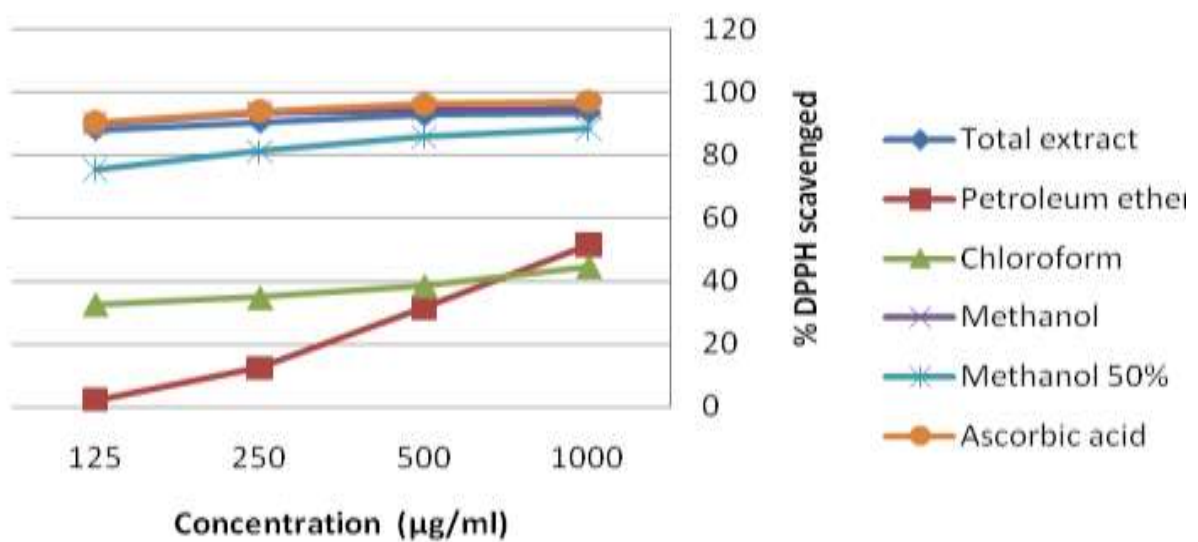

Fig. (3). The percentages of scavenging activities for total extract and successive extraction residues of Phlomis floccosa flowers.

\section{IC ${ }_{50}$ of Different Parts of Phlomis floccosa}

The obtained results showed that, the essential oils doesn't have antioxidant activity. The highest percentage of DPPH scavenging activity for total and successive extracts residues of different parts (stems, leaves and flowers) of Phlomis floccosa was methanol extracts (Table 5). The DPPH radical scavenging activity of methanol extract may be mostly related to the presence of flavonoids. Hence methanol extracts was analyzed by HPLC. 
Table (5). $\mathrm{IC}_{50}(\mu \mathrm{g} / \mathrm{ml})$ of different parts of Phlomis floccosa.

\begin{tabular}{lccc}
\hline Solvent used & \multicolumn{3}{c}{ IC $_{\mathbf{5 0}}(\boldsymbol{\mu g} \mathbf{g} / \mathbf{m l})$} \\
\cline { 2 - 4 } & Stems & Leaves & Flowers \\
\hline Total extract & 42.36 & 67.41 & 92.90 \\
Petroleum ether & 291.4 & 399.0 & 906.9 \\
Chloroform & 49.44 & 217.6 & 2713 \\
Methanol & 36.36 & 40.07 & 27.49 \\
Methanol 50\% & 47.68 & 153.4 & 96.52 \\
Ascorbic acid & 17.63 & 17.63 & 17.63 \\
\hline
\end{tabular}

\section{Qualitative and Quantitative Analysis of the Methanol Extracts of Different Parts of Phlomis floccosa}

Investigation of methanol extracts by HPLC revealed the presence of 21 flavonoid compounds at different parts (stems, leaves and flowers) of Phlomis floccosa, where the major compounds were luteolin-6-glucose-8arabinose $(1234.3 \mathrm{mg} / 100 \mathrm{~g}, 1098.2 \mathrm{mg} / 100 \mathrm{~g}$ and $440.17 \mathrm{mg} / 100 \mathrm{~g})$ in stems, leaves and flowers of Phlomis floccosa, respectively. While luteolin6-arabinose-8-glucose was the second major compound in stems and flowers $(144.47 \mathrm{mg} / 100 \mathrm{~g}$ and $375.3 \mathrm{mg} / 100 \mathrm{~g}$ ), respectively, but the second major compound in leaves was naringenin $(278.13 \mathrm{mg} / 100 \mathrm{~g})$ (Table 6).

Flavonoids have great importance as antioxidants in vitro, due to the high number of hydroxyl groups in their molecules. The glycosylation of flavonoids reduces their in vitro antioxidant activity, when compared with the corresponding aglycons. The main structural features of flavonoids required for efficient radical scavenging could be summarized as follows: an ortho-dihydroxy (catechol) structure in the $\mathrm{B}$ ring, for electron delocalization, 2, 3-double bond in conjugation with a 4-oxo function in the $\mathrm{C}$ ring provides electron delocalization from the $\mathrm{B}$ ring, hydroxyl groups at positions 3 and 5 provide hydrogen bonding to the oxo group (Prochazkova et al., 2011).

HPLC analysis of the methanol fractions showed that, the highest content of the different parts of the plant was luteolin-6-glucose-8-arabinose. Concerning its structure, the previously mentioned features required for free radical scavenging activity are fulfilled. 
Table (6). HPLC analysis of the methanol extracts of different parts (stems, leaves and flowers) of Phlomis floccosa.

\begin{tabular}{clccc}
\hline \multirow{2}{*}{ No. } & Flavonoids & \multicolumn{3}{c}{ Concentration $(\mathbf{m g} / \mathbf{1 0 0}$ g) } \\
\cline { 3 - 5 } & & Stem & Leaves & Flowers \\
\hline 1 & Luteolin-6- arabinose-8- glucose & 144.47 & 119.35 & 375.30 \\
2 & Luteolin-6- glucose -8- arabinose & 1234.30 & 1098.2 & 440.17 \\
3 & Apigenin-6- arabinose -8-glactose & 65.70 & 27.91 & 48.19 \\
4 & Apignin-6- rhamnose -8- glucose & 7.50 & 15.29 & 31.32 \\
5 & Apignin-6- glucose -8- rhamnose & 76.79 & 43.82 & 187.08 \\
6 & Luteolin-7- glucose & 6.58 & 20.40 & 12.76 \\
7 & Narengin & 13.04 & 24.32 & 73.14 \\
8 & Rutin & 4.39 & 1.61 & 13.24 \\
9 & Hespiridin & 31.41 & 11.15 & 15.59 \\
10 & Rosmarinic & 1.24 & 1.69 & 8.75 \\
11 & Apigenin-7-O- neohespiroside & 1.67 & 3.53 & 2.58 \\
12 & Kampferol-3,7-dirhamoside & 5.64 & 4.05 & 2.48 \\
13 & Apigenin-7- glucose & 5.64 & 11.98 & 5.43 \\
14 & Quercetrin & 4.30 & 1.74 & 2.47 \\
15 & Quercetin & 3.31 & 5.56 & 0.66 \\
16 & Naringenin & 78.96 & 278.13 & 254.46 \\
17 & Hespirtin & 6.62 & 12.98 & 26.58 \\
18 & Kampferol & 0.84 & 1.30 & 0.77 \\
19 & Rhamnetin & 1.73 & 3.27 & 1.77 \\
20 & Apignin & 1.05 & 0.93 & 4.79 \\
21 & Acacetin & 15.05 & 9.48 & 9.06 \\
\hline
\end{tabular}

\section{CONCLUSION}

This study on the antioxidant activity of Phlomis floccosa showed that, the hydro-distillation of the leaves of Phlomis floccosa yielded 0.18\% of clear yellowish liquid oil and it didn't has antioxidant activity. On the other hand it could be concluded that the methanol extract exhibited promising free radical scavenging activity compared with ascorbic acid. This antioxidant activity is due to the high content of the detected flavonoids (21 compounds).

\section{REFERENCES}

Adams, R.P. (1995). In "Identification of Essential Oil Components by Gas Chromatography/Mass Spectroscopy". Illinois, Allured Publ. Corp., pp. 69-351. 
Amor, L.B., J. Boubaker, M.B. Sgaier, I.S. Kandrani, W. Bhouri, A.S. Neffati Kilani, I. Bouhlel, K.K. Ghedira and L. Chekir-Ghedira (2009). Phytochemistry and biological activities of Phlomis species, J. Ethnopharmcol., 125: 183-202.

Azad, A.N., V. Hakimzadeh and E. Golmakani (2015). Phenolic contents and antioxidants activity from aerial parts of Phlomis herba-venti L. subsp. kopetdaghensis. J. Appl. Environ. Biol. Sci., 4 (11S): 54-58.

Barros, L., S.A. Helano, A.M. Carvalho and I.C.F.R. Ferreira (2010). Lamiaceae often used in Portuguese folk medicine as a source of powerful antioxidants: vitamins and phenolics. LWT., 43: 544-550.

Delnavazi, M., F. Baba-Ali, S. Soufiabadi, M. Sherafatmand, F. Ghahremani, S. Tavakoli and N. Yassa (2014). Essential oil composition, antioxidant activity and total phenolic content of some Lamiaceae taxa growing in northwest of Iran. Pharmaceutical Sciences, 20 (1): 22-28.

Denny, E.F.K. (1989). Hydro-distillation of oils from aromatic herbs. Perfum. Flavor., 14: 57-63.

El-Negoumy, S. I., M.F. Abdalla and N.A.M. Saleh (1986). Flavonoids of Phlomis aurea and P. floccose. Phytochemistry, 25 (3): 772-774.

Kamatou, G.P.P., A.M. Viljoen and P. Steenkamp (2010). Antioxidant, antiinflammatory activities and HPLC analysis of South African Salvia species. Food Chem., 119: 684-688.

Li, M.X., X.F. Shang, Z.P. Jia and R.X. Zhang (2010). Phytochemical and biological studies of plants from the Genus Phlomis. Chem. Diver., 7: 283-301.

Mattila, P., J. Astola and J. Kumpulainen (2000). Determination of flavonoids in plant material by HPLC with diode-array and electroarray detections. J. Agric. Food Chem., 48: 5834-5841.

Prochazkova, D., I. Bousova and N. Wilhelmova (2011). Antioxidant and pro-oxidant properties of flavonoids. Fitoterapia, 82 (4): 513-523.

Swigar, A.A. and R.M. Silverstein (1981). In "Monoterpenes, Infrared, Mass, ${ }^{1} \mathrm{H}-\mathrm{NMR},{ }^{13} \mathrm{C}-\mathrm{NMR}$ Spectra and Kovats Indices". Aldrich Chemical Company Inc., Wisconsin, pp. 1-121.

Yildirim, A., A. Mavi and A. Kara (2001). Determination of antioxidant and antimicrobial activities of Rumex crispus L. extracts. J. Agri. Food. Chem., 49: 4083-4089.

Yumrutas, O. and S.D. Saygideger (2012). Determination of antioxidant and antimutagenic activities of Phlomis armeniaca and Mentha pulegium. Journal of Applied Pharmaceutical Science, 2 (1): 36-40. 
التركيب الكيميائي والنشاط المضاد للأكسدة للزيت العطري وفلافونيدات نبات ضرس الثايب

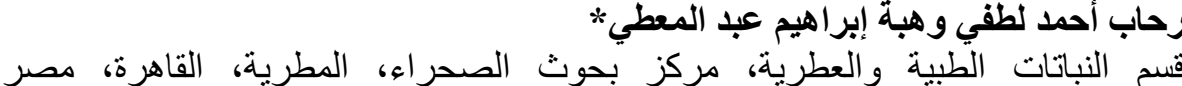

يهدف هذا البحث إلى دراسة الفاعليات المضادة للأكسدة من زيوت أساسية ومستخلصات

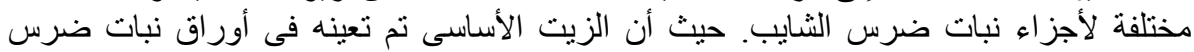

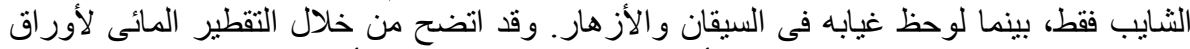

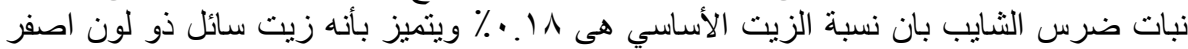

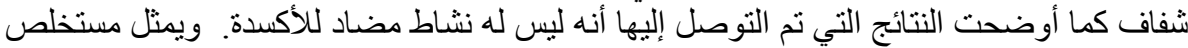

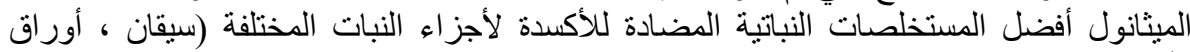

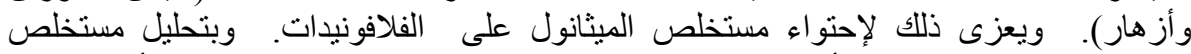

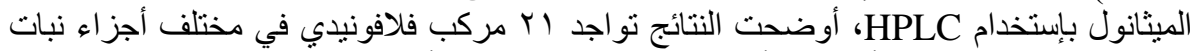

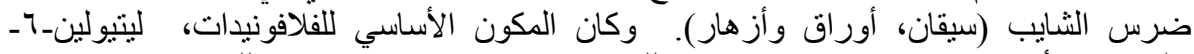

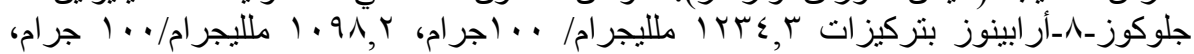

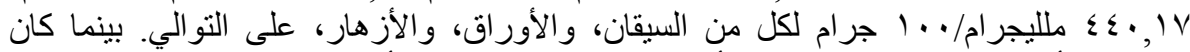

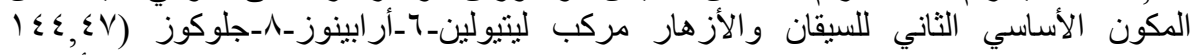

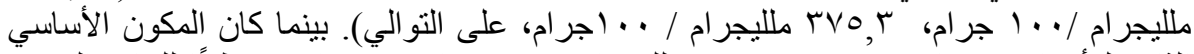

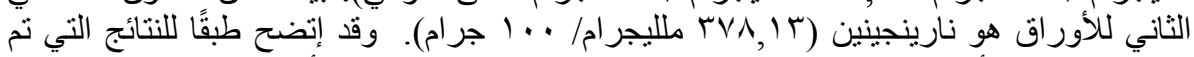
الحصول عليها أن مستخلص الميثانول لنبات ضرس الثنايب يمكن أن يكون مصدرا طبيعيا لمضادات الأكسدة.

Egyptian J. Desert Res., 65, No. 1, 125-135 (2015) 